\title{
POTENTIAL OF FEEDING CRUDE PALM OIL AND CO-PRODUCTS OF PALM OIL MILLING ON LAYING HENS' PERFORMANCE AND EGG QUALITY: A REVIEW
}

\author{
MOOKIAH SAMINATHAN*; WAN NOORAIDA WAN MOHAMED*; 'ABIDAH MD NOH*; \\ NUR ATIKAH IBRAHIM*; MUHAMMAD AMIRUL FUAT*; NOOR LIDA HABI MAT DIAN* \\ and SURIYA KUMARI RAMIAH**
}

\begin{abstract}
Crude palm oil (CPO) and the main co-products of palm oil milling, namely, palm kernel cake (PKC) and palm oil mill effluent (POME) have considerable potential nutritive value for laying hens. This review was conducted to study the effect of CPO, PKC and POME as feed ingredients on growth performance of laying hens and egg quality traits. CPO provides high caloric levels, and its inclusion in laying rations enhances the absorption of oil-soluble vitamins. High carotenoids (500-700 ppm) content in CPO improves egg quality by increasing the fatty acid content and colour intensity of egg yolk. Laying hens can tolerate up to 20\%-30\% PKC in the diet with no adverse effects on growth performance or egg quality traits. POME can be used as a feed ingredient for laying hens, and the recommended optimal level of inclusion is $10 \%$ of the total ration. However, due to high levels of fibrous matter in PKC and POME, further biotechnology treatments are needed for better utilisation in laying hens' rations to yield optimum egg production. Replacement of the conventional feed ingredient in the laying ration with PKC and POME were found to be cost-effective in improving layer performance and egg quality.
\end{abstract}

Keywords: crude palm oil, oil palm co-products, palm kernel cake, laying hens, performance, egg quality.

Received: 3 March 2020; Accepted: 12 April 2020; Published online: 11 September 2020.

\section{INTRODUCTION}

Hen eggs are an affordable foodstuff and are nutrient-dense food component that can contribute to healthy diet. Eggs contain good-quality protein and lipids as well as many micronutrients, including essential and non-essential vitamins and minerals (ENC, 2014). During the last three decades, the world's egg production has increased dramatically, and Asia is the major consumer (FAO, 2018).

\footnotetext{
Malaysian Palm Oil Board,

6 Persiaran Institusi, Bandar Baru Bangi,

43000 Kajang, Selangor, Malaysia.

E-mail: saminathan@mpob.gov.my

** Institute of Tropical Agriculture and Food Security, Universiti Putra Malaysia, 43400 UPM Serdang,

Selangor, Malaysia.
}

Egg nutrient composition and quality are affected by diet, heredity, environment and the hen's age (Koelkebeck, 2014). Variation in nutrients composition of laying hens' feed can greatly impact the egg nutrition components such as vitamins, minerals, omega-3 polyunsaturated fatty acids (PUFA) and lutein that is favourable to human health (Walker et al., 2012; Yao et al., 2013). Improved performance and egg quality traits and composition have been observed in laying hens conventional diets containing ingredients such as maize, wheat, barley, oil cake and fishmeal (Swain et al., 2014). However, in the past decade, a dramatic global increase in the price of conventional feedstuffs has occurred due to shortages resulting from the competition between humans and livestock for conventional foodstuffs (FAO, 2018). To sustain 
the optimal laying hen's performance and egg productivity at the lowest cost, incorporation of cheaper and more readily available alternative feedstuffs into livestock diets is vital.

The oil palm (Elaeis guineensis), belonging to the family Palmae, is a valuable agricultural crop that is used to produce palm oil and other oil palm products. Palm oil is extracted from fresh fruit bunches (FFB) by a mechanical process. Figure 1 presents a typical palm oil processing flow diagram. Solid waste materials and co-products are generated from the palm oil milling process. Inclusion of oil palm industry products and co-products as a nonconventional alternative food source for poultry is of primordial prominence in tropical countries due to its availability and cost-effectiveness compared to conventional feedstuffs. A schema showing how oil palm primary products and co-products that are available to the feed industry are produced during the palm oil milling process is shown in Figure 2. The palm oil mill and palm kernel crushing plant produce crude palm oil (CPO) and crude palm kernels oil (CPKO), respectively, as primary products, and biomass such as palm kernel cake (PKC) and palm oil mill effluent (POME) or palm oil sludge as secondary/co-products from fresh fruit bunches (Foong et al., 2019). CPO, PKC and POME having considerable potential nutritive value have been used as feed ingredients for laying hens, for decades. The nutritive properties of these products, particularly their high content of metabolisable energy (ME), crude protein (CP), antioxidant compounds (especially vitamin $\mathrm{E}$ and carotenes) and minerals, could provide significant benefits for laying hen's performance, egg production and egg composition, and the prospect for increasing their usage in the poultry diet is huge (Tafsin et al., 2017). There are extensive information on the nutritive value, biochemical properties, development methods and feeding response of laying hens fed oil palm products and co-product-based diets. This article reviews the potential use of $\mathrm{CPO}$ and the coproducts from palm oil milling (PKC and POME) to improve laying hens' performance and egg production and quality traits.

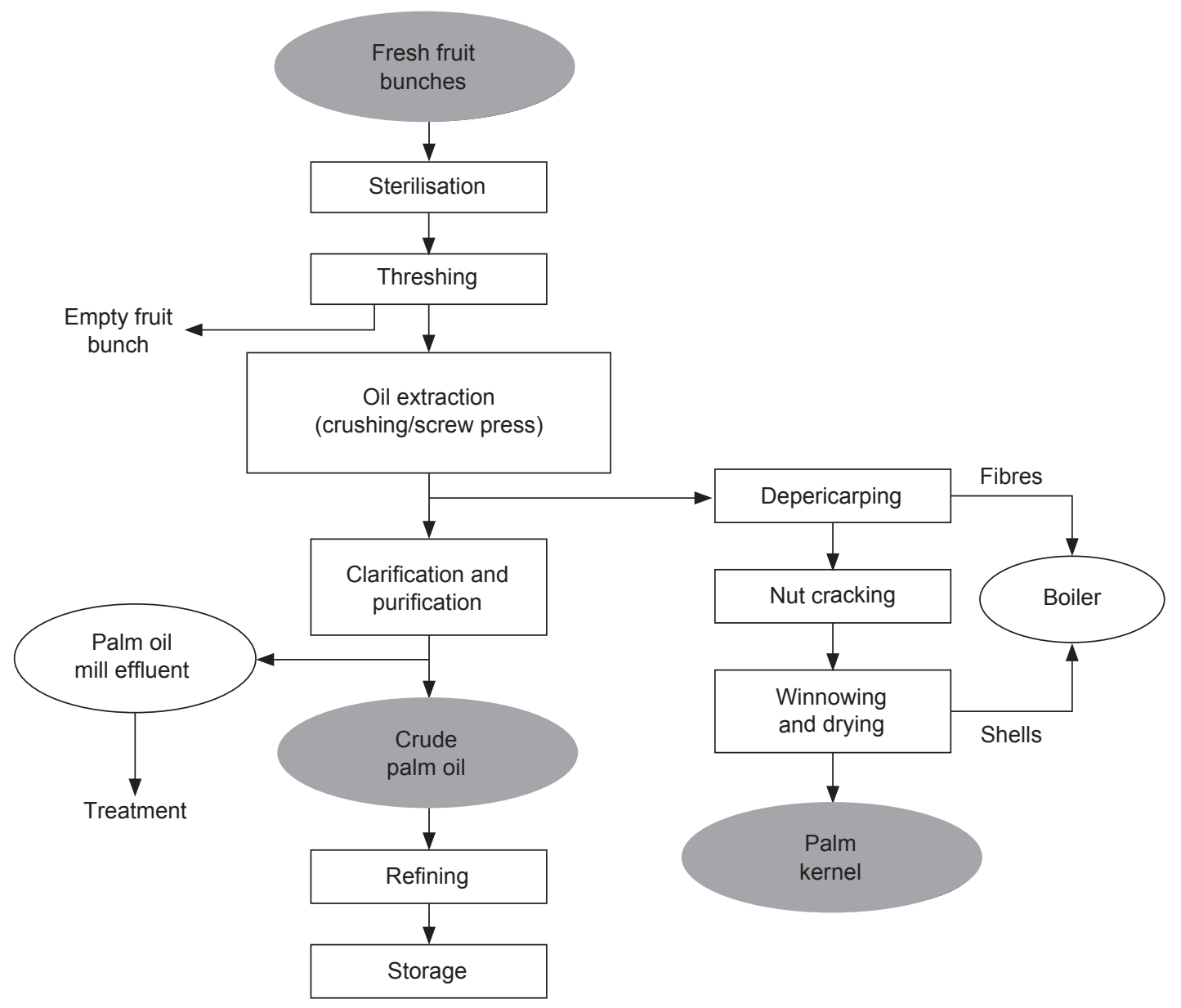

Source: FAO (2002).

Figure 1. Palm oil processing flow chart. 


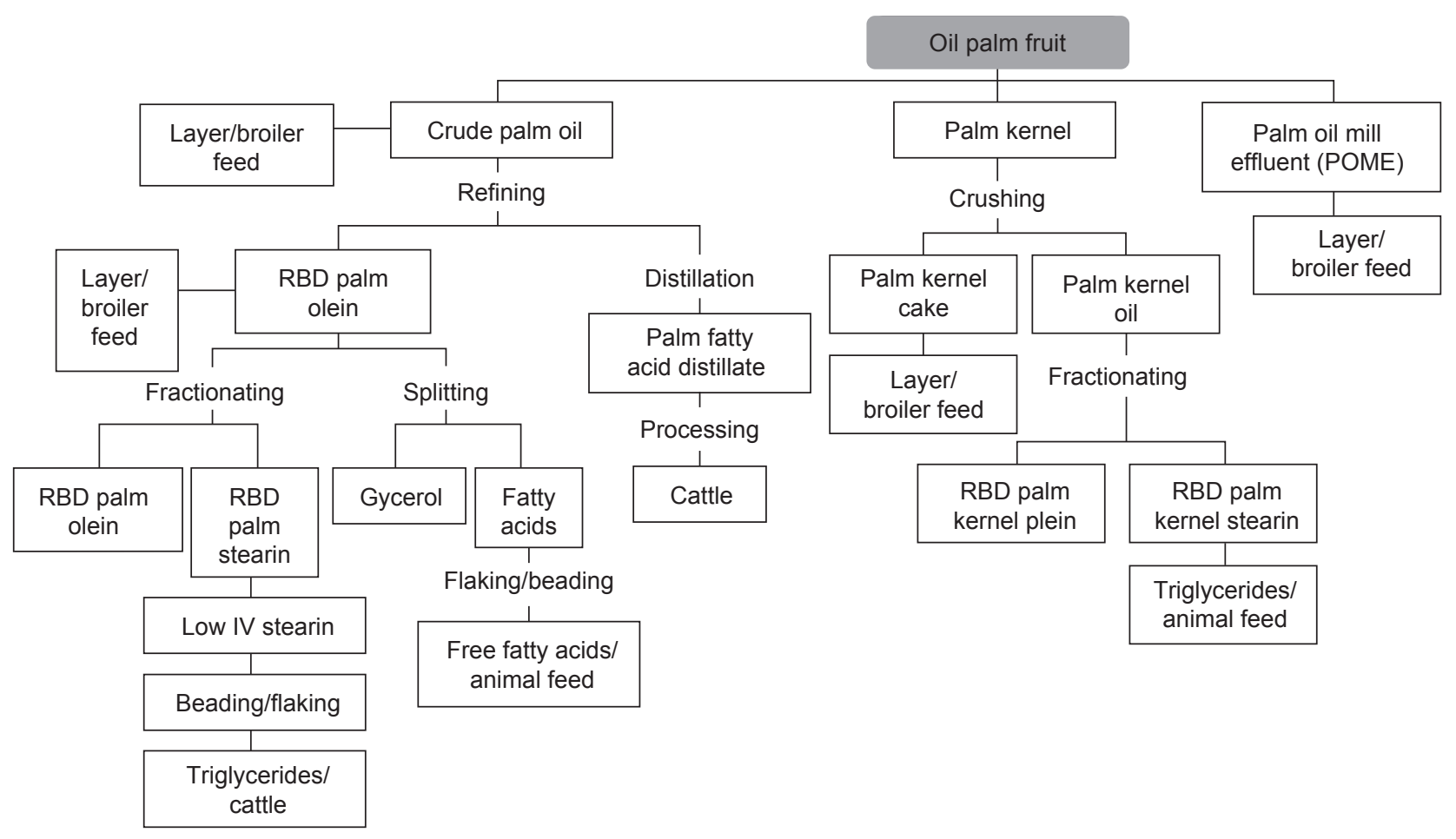

Note: RBD - refined, bleached and deodourised.

IV - iodine value.

Figure 2. Schema for palm oil manufacturing and co-products for poultry feed.

\section{EFFECT OF CRUDE PALM OIL ON LAYING HEN'S PERFORMANCE AND EGG QUALITY}

Digestibility of $\mathrm{CPO}$ in poultry is influenced profoundly by saturation, the content of unesterified fatty acids, and by age of the birds (Palmquist, 2004). Tomkins and Drackley (2010) suggested the digestibility of vegetable oil is lower in young birds than in mature birds due to undeveloped bile salt system in the young animal and the emulsifiers improve the digestion of dietary lipids in poultry. Higher saturation and unesterified fatty acids greatly decreased digestibility in birds at 1.5 weeks of age compared with 7.5 weeks (Palmquist, 2004). CPO has been traditionally used as an ingredient (approximately 3\%-5\% of the diet) in feed for laying hens due to its tremendous value as a source of lipids, an energy source and a source of vitamins A and $\mathrm{D}$ as well as to reduce the dustiness of the diet (Tomkins and Drackley, 2010; Akter et al., 2014). CPO is particularly rich in natural vitamin $\mathrm{E}$ (specifically tocotrienols and tocopherols) and may confer specific health benefits such as hypocholesterolaemic, neuroprotective and anti-carcinogenic properties. Eggs can be enriched with functional compounds by biotransfer of these substances from feed to eggs.

Egg yolks enriched in vitamin E can be obtained by incorporating CPO in the laying hens' diet (Kang et al., 1998). Due to vitamin $\mathrm{E}$ is not usually among the ingredients naturally present in feeds, their enhancement in feeds via the incorporation of $\mathrm{CPO}$ results in a stable improvement in eggs that is dosedependent. Vitamin E from CPO, which is known to be efficient lipid-soluble chain-breaking antioxidants, prevent egg cell membranes from being attacked by lipid molecular oxygen (peroxyl) radicals in eggs (Atabo et al., 2018). CPO is also rich in carotenoids (mainly $\alpha$-carotene and $\beta$-carotene). Incorporation of CPO could result in significant integration of retinol in the eggs, where $\beta$-carotene is the precursor (inactive form) for the formation of retinol from enzymatic oxidative cleavage of $\beta$-carotene by enzyme $\beta$-carotenoid 15, 15'-dioxygenase (Wu et al., 2016).

A recent study showed that dietary inclusion of CPO $(2 \%-4 \%$ of the diet) significantly increased egg production, egg yolk colour, and egg and yolk weight but not shell weight, albumen weight or specific gravity compared to the control group (Areerob et al., 2018). Importantly, Areerob et al. (2018) observed that the diet supplemented with the highest level of CPO $(4 \%)$ reduced egg yolk cholesterol levels and enhanced the total vitamin E and carotenoid levels in eggs. Earlier, Hodzic et al. (2008) also found that incorporation of CPO into layer rations could decrease egg and yolk cholesterol levels. In another study, Punita and Chaturvedi (2000) observed a maximum reduction in the total lipid content of hens' eggs with the dietary inclusion of two hypocholesterolemic agents, CPO and grain 
amaranth, either individually or in combination. The hypocholesterolemic effect of the CPO may be linked to its high tocotrienol content, which has been reported to decrease hepatic 3-hydroxy-3methylglutaryl-coenzyme A (HMG-CoA) reductase activity and to act as an oxidised sterol, thereby reducing cholesterol levels (Qureshi et al., 1991).

In contrast, Akter et al. (2014) found that supplementation of laying hens' diets with $\mathrm{CPO}$ at levels of $1.5 \%, 3.0 \%$ and $5.0 \%$ had no significant effect on egg weight, Haugh unit (HU), shape index, egg shell weight or albumen or yolk weight as a percentage of egg weight. They also found that CPO, which is known to be rich in saturated fatty acids, did not result in a significant increase in egg shell thickness at any of the inclusion levels tested. The reason could be that several dietary oils supplementation might impair calcium (Ca) and phosphorus (P) absorption due to increased saponification with feed minerals and decreased absorption of $\mathrm{Ca}$ and $\mathrm{P}$ by the gut system of hens and thus affect the egg shell thickness and reduce egg specific gravity (Abdulla et al., 2017). A number of studies has shown that dietary fat sources such as CPO had no significant effect on albumen weight, albumen height or HU because all the diets used had similar energy and protein (isonitrogenous and isocaloric) contents according to the hens' nutrient requirements. On the other hand, the rate of hepatic synthesis of fats might be sufficient to supply the amount of lipids needed to achieve optimal egg albumen and yolk weights, and exogenous fat may not be necessary to meet these requirements.

The inclusion of increasing amounts of $\mathrm{CPO}$ in poultry feed is positively correlated with the yolk colour score, as explained by Ping and Gwendolin (2006) and Tranbarger et al. (2011). As hens are unable to synthesise egg colouration pigments, the colouration of the egg yolk depends on the absorption and deposition of pigmenting agents from the diet. Dietary carotenoids are commonly used to produce yellow-coloured yolks, whereas capsanthin, capsorubin and canthaxanthin are often used to produce red-coloured yolks (Sandeski et al., 2014). Kang et al. (1998) explained that CPO contains adequate amounts of $\beta$-carotenoids, which escapes from absorption in gut and impairs transportation to ovarian follicles and thus have a major impact on yolk colour. Moreover, CPO naturally consists about $90 \%$ carotene ( $\alpha$ - and $\beta$-carotene) and 10\% xanthophylls of the total carotenoids, which are essential for production of eggs with yellowcoloured yolks (Goh et al., 1985). Akter et al. (2014) found that yolk colour was significantly enhanced when the amount of $\mathrm{CPO}$ in the diet was increased; eggs from hens in the group that received $5.0 \%$ of $\mathrm{CPO}$ showed the highest yellow-coloured yolk score (5.69), followed by eggs from hens that received $3.0 \%$ of $\mathrm{CPO}(4.80), 1.5 \%$ of $\mathrm{CPO}$ (3.69) and basal diets (2.19), respectively. The improvement in egg yolk colour score from hens fed different diets can be attributed to the increasing dietary level of $\mathrm{CPO}$, which is enriched in the yellow pigment xanthophyll, a lipid-like compound derived from the carotenoid group (Ping and Gwendolin, 2006).

$\mathrm{CPO}$-supplemented laying hens may have lower levels of thiobarbituric acid-reactive substances (TBARS) and thus produce eggs with relatively lower levels of TBARS, resulting in an increase in the vitamin $\mathrm{E}$ (tocotrienols and tocopherols) and retinol content of the eggs (Kang et al., 1998; 2001). In agreement with previous findings, Akter et al. (2014) revealed that among the $\mathrm{CPO}$ treatments, eggs from hens that received diets higher in $\mathrm{CPO}$ had lower TBARS, indicating that absorption of more natural antioxidants from $\mathrm{CPO}$ resulted in increased lipid stability in eggs without affecting the egg quality characteristics. The synergistic effect of vitamin E (tocotrienol and tocopherol) and carotenoids present in the $\mathrm{CPO}$ might improve the oxidative stability of egg yolk, egg quality, and reduce the development of undesirable flavours while increasing egg production (Panda and Cherian, 2014).

\section{EFFECTS OF PKC INCLUSION ON LAYING HEN PERFORMANCE AND EGG QUALITY}

PKC is an important residue produced by the oil palm industry. It is also known as palm kernel meal (PKM) or palm kernel expeller (PKE). In an ideal milling process, oil can be extracted commercially from palm kernels via two key methods, i.e., mechanical expression and solvent extraction. PKM or PKC, and PKE are the residue remaining after the solvent and expeller extraction of oil from palm kernels, respectively. Due to the general lack of discrimination between these two products, the term 'PKC' will be used throughout this review to refer to both products. Most of the PKC are used in animal feeding for fattening, as well as providing protein, energy, vitamins and minerals that required by various livestock for optimal growth performance (Abdeltawab and Khattab, 2018).

\section{Growth Performance}

PKC has been widely studied for use as a source of protein and energy in both laying hens and broiler chickens. It has been suggested that the incorporation of PKC in broiler or laying hen rations at the optimal level of $20 \%-30 \%$ as a partial replacement for corn and soyabeans results in a reduction in the cost of poultry feed (Alimon and Wan Zahari, 2012; Yusrizal et al., 2013; Chen et al., 2015). Mohamed et al. (2012) suggested that utilisation of PKC as poultry feed ingredient at higher inclusion levels become limited due to its 
high fibre and shell content. However, to date, reports on the optimal feeding level of PKC in layers' diets and the effects of these diets on growth performance have been inconsistent. Sundu et al. (2006) speculated that these dissimilarities are due to differences in the total fibre content, the degree of grittiness and the amino acid content of PKC. Several studies have reported that inclusion of 30\%$40 \%$ of PKC in the layer's diet did not significantly affect body weight gain (BWG) compared to a diet containing maize-groundnut cake (Onwudike, 1988; Radim et al., 2000; Odunsi et al., 2002). Shakila et al. (2012) found that BWG of breeder-type layers fed 7.5 and $15 \%$ PKC were comparable with those fed with basal diet containing de-oiled rice bran (DORB) at 41 and 60 weeks of age. In contrast, Zanu et al. (2012) found that the inclusion of PKC in the diet at increasing levels $(5 \%, 10 \%$ and $15 \%)$ significantly reduced the BWG of Lohmann Brown laying hens compared to a basal diet $(0 \%$ PKC). A negative correlation between the level of PKC included in the ration and the BWG of hens may be attributed to the higher fibre content and lower nutrient digestibility of diets containing PKC. PKC might also undergo the Maillard reaction (a reaction between amino groups and the mannanose in PKC that forms a brown complex matter) during oil extraction under heat, and this may adversely affect its digestibility (Sundu and Dingle, 2003). Furthermore, high shell content of PKC might affect the feeding value for animal in terms of low protein content and energy availability. Recently, a premium grade PKC which is less shell $(<4 \%)$ content has been commercially developed in concordance of its better usage as a feed ingredient for broiler chicken that able to enhance the growth performance comparable to that of commercial chicken (Halim et al., 2017).

The feed intake (FI) of layer hens' diets containing PKC is typically higher than that of hens fed a maize-based diet due to the more rapid transit rate of digesta derived from the former diets in the gastrointestinal tract (GIT) and their lower water-holding capacity and higher bulk density, all of which are believed to increase FI in birds (Akpodiete, 2008). In addition, PKC is a fibrous feed that releases less of its nutrient content because the nutrients are diluted by the fibre. Thus, layer hens are able to regulate their FI to obtain the necessary daily dietary energy level for optimal production performance. An increase in the FI of hens fed PKCbased layer rations could also be due to an increase in the palatability of feed as a result of presence of residual palm oil in PKC. Consistent with this, Odunsei et al. (2002) and Adrizal et al. (2011) found that cumulative FI was increased in native layers fed an isocaloric diet containing 30\% of PKC compared to layers fed a diet containing maize-groundnut cake. Chong et al. (2008) suggested that when the poultry diet is isocaloric, birds might consume more feed to meet their amino acid requirements. An increase in FI may be due to the fibrousness of the diet $[4.45 \%$ to $7.78 \%$ crude fibre $(\mathrm{CF})]$ of the ration because PKC is defined as high CF (16.2\%-25.3\%) considering that fibre accounts for $80 \%$ of the nonstarch polysaccharides (NSP) of the dry matter (DM).

However, studies by Perez et al. (2000) and Iyayi and Aderolu (2004) on the effect of the inclusion of PKC in laying hen diets reported that addition of PKC at various levels (7.5\%-50\%) did not influence FI or feed conversion ratio (FCR) compared to a maize-groundnut cake-based control diet. These findings suggest that PKC has relative benefit as a potential feed ingredient for laying hens in terms of digestion and nutrient availability. In contrast, Onwudike (1988) observed that layers' diets containing 50\%-70\% of PKC impaired FI in layer hens (31 weeks old) over a six-month experimental period. A study conducted by Afolabi et al. (2012) showed that the daily FI of local hens (63.97 to 73.44 $\mathrm{g} /$ bird per 12 weeks) was significantly lower when PKC was included at levels of $10 \%, 20 \%$ and $40 \%$ than birds fed a basal diet (64.02 $\mathrm{g} /$ bird per day) but not when they were fed a diet containing 50\% PKC. In the same study, lower FCR was observed in hens fed diets containing 20\% to $40 \%$ of PKC, indicating more efficient and more favourable FCR than that found in hens fed diets containing 50\% PKC. The reasons for the inconsistency of these results are unclear, but it is hypothesised that the differences could be associated with the biochemical properties of the PKC, including its amino acid composition, its high CF and energy content, its mineral nutrient content and its unpalatability (Sharmila et al., 2014).

The nutritional value of PKC for animal feed can be improved by the use of solid-state fermentation (SSF) and by the addition of exogenous enzymes. Mannanase can be used for the fermentation of NSP (mannans), resulting in an improved bioavailability of simple sugars as an energy source (Düsterhöft et al., 1992; Daud and Jarvis, 1992). Enzymatic depolymerisation of mannans may release monoor di-saccharides that will be easily absorbed and metabolised by poultry (Saenphoom et al., 2013). Chemical treatment of PKC with acidic (acetic and formic acids) or alkaline (ammonium hydroxide) solutions has also been proposed to improve the PKC nutritive values by increasing the $\mathrm{CP}$ content and decreasing the fibre content (A'dilah and Alimon, 2011). Fermentation of PKC using microbial biotechnology increased the CP content (15\%-35\%) as well as the true metabolisable energy (TME) value (5.5-8.1 MJ kg-1) of PKC. Dairo and Fasuyi (2008) found that fermented PKC could increase the CP content from $20.04 \%$ to $23.42 \%$ and decreased the CF from $15.47 \%$ to $12.44 \%$. This implies that fermented PKC can be used to substitute for the expensive soyabean meal protein in laying hens' diets. Several studies have reported improvements in nutrient 
digestibility and nutritional values of PKC via SSF using potential cellulolytic and hemicellulolytic bacteria, proteolitic bacteria and fungi for poultry feeding (Rahim et al., 2007; Alshelmani et al., 2013; 2014; 2016; 2017; Muangkeow and Chinajariyawong, 2009; 2013). These microbial cultures can change the chemical or physico-chemical properties of the PKC substrate as well as having the ability to produce multiple enzymes to breakdown the $\beta$-glycosidic bonds that link the cellulose, xylan and mannan in the PKC (Table 1). Therefore, releasing more sugars improve the nutritive value of PKC. In addition, the nutritive value of PKC fermented by microbes was improved, and it could be beneficial in terms of nutrient digestibility, intestinal microflora, ileal microbial fermentation and poultry performance (Marini et al., 2005).

Dairo and Fasuyi (2008) reported that overall BWG was significantly improved in 37-week old layers fed fermented PKC at $75 \%$ as a replacement for soyabean meal protein for 12 weeks. Chong et al. (2008) found that FI was significantly lower in layers fed diets containing PKC at 25\% with $0.1 \%$ enzyme supplementation. However, laying hens fed diets containing $<25 \%$ of PKC with the inclusion of NSP enzymes showed better FCR than hens fed PKC without enzyme supplementation (Chong et al., 2008). Apart from laying hens, Soltan (2009) found that the negative effect of feeding a $20 \%$ PKC ration on broiler growth performance could be improved by the addition of a mixture of enzymes that included cellulose, xylanase, amylase, protease, $\beta$-gluconase and lipase. Chong et al. (2008) reported that inclusion of PKC at $12.5 \%$ and $25 \%$ with addition of an NSP enzyme in the diets of laying hens did not adversely affect the animals' growth performance. The enhanced growth performance observed in the birds fed fermented PKC could be attributed to the reduction in the amounts of NSP and complex carbohydrates in PKC when the feed was supplemented with enzymes.

\section{Egg Production and Egg Quality Traits}

It is acceptable to include up to $25 \%$ of PKC in laying hens' feed to achieve optimal growth performance without any detrimental impact on egg weight on external and internal quality (Yeong et al., 1981; Yeong, 1987; Radim et al., 2000). Consistent with this, Chong et al. (2008) found that dietary inclusion of $25 \%$ of PKC containing NSP enzyme in the layer diet did not show detrimental effects on egg quality traits. While, several studies have found no negative effects on egg production or quality traits in laying hens fed rations containing up to $40 \%$ of PKC (Onwudike, 1988; Perez et al., 2000; Akpodiete, 2008). Notwithstanding that, a study by Longe (1984) found lower tolerable levels of PKC $(<20 \%)$ in laying hens.

Afolabi et al. (2012) evaluated the effects of different dietary levels of PKC with added palm oil on the egg quality traits of Nigerian hens. The results showed that dietary PKC levels of $20 \%-40 \%$ resulted in significantly higher hen-day production (HDP) compared with hens fed a basal diet without PKC or a diet consisting of 50\% PKC. However, the positive effects of PKC on egg quality traits were not observed in laying hens' fed diets containing any of the PKC ration levels tested (10\%-50\%). A significant positive impact on HDP associated with the inclusion of varying levels $(0 \%-50 \%)$ of PKC in the diet was also reported by Longe and Adekoya (1988) and Perez et al. (2000). Onwudike (1992) obtained FCR values in the range of about 3.09-3.12

TABLE 1. SOLID-STATE FERMENTATION OF PALM KERNEL CAKE AND ENZYMES INVOLVED FOR POULTRY FEEDING

\begin{tabular}{|c|c|c|c|}
\hline Microorganism & $\begin{array}{l}\text { Enzymes involved during } \\
\text { fermentation }\end{array}$ & $\begin{array}{l}\text { Bioreactor (duration } \\
\text { and temperature) }\end{array}$ & References \\
\hline Rhizopus sp. & Protease, lipolise and amylase & - & Rahim et al. (2007) \\
\hline Fibre degrading bacteria & Cellulase, mannanase, xylanase & Flask ( 4 to $7 \mathrm{~d}$ at $30^{\circ} \mathrm{C}$ ) & Alshelmani et al. (2013) \\
\hline $\begin{array}{l}\text { Cellulolytic and hemicellulolytic } \\
\text { bacteria }\end{array}$ & Cellulase, mannanase, xylanase & Flask $\left(12 \mathrm{~d}\right.$ at $\left.30^{\circ} \mathrm{C}\right)$ & Alshelmani et al. (2014) \\
\hline Paenibacillus polymyxa & Cellulase, mannanase, xylanase & Flask $\left(9 \mathrm{~d}\right.$ at $\left.30^{\circ} \mathrm{C}\right)$ & Alshelmani et al. (2016) \\
\hline $\begin{array}{l}\text { Cellulolytic bacteria (Paenibacillus } \\
\text { polymyxa and Paenibacillus curdlanolyticus) }\end{array}$ & Cellulase, mannanase, xylanase & Flask ( 4 to $7 \mathrm{~d}$ at $30^{\circ} \mathrm{C}$ ) & Alshelmani et al. (2017) \\
\hline Aspergillus wentii & $\begin{array}{l}\text { Amylase, lipase, dextranase, cellulase, } \\
\text { pectinase, } \beta \text {-glucosidase, mannanase, } \\
\text { xylanase }\end{array}$ & - & $\begin{array}{l}\text { Muangkeow and } \\
\text { Chinajariyawong } \\
\text { (2009) }\end{array}$ \\
\hline Aspergillus wentii & $\begin{array}{l}\text { Amylase, lipase, dextranase, cellulase, } \\
\text { pectinase, } \beta \text {-glucosidase, mannanase, } \\
\text { xylanase }\end{array}$ & - & $\begin{array}{l}\text { Muangkeow and } \\
\text { Chinajariyawong } \\
\text { (2013) }\end{array}$ \\
\hline
\end{tabular}

Note: d - days. 
and a better HDP when feeding the Harco strain of laying hens with diets $20 \%-40 \%$ PKC-based. In the majority of cases, the incorporation of PKC at various levels (0\%-50\%) has no negative impact on egg quality traits, indicating that the PKCbased feed was nutritious and useful despite its fibrousness and imbalanced amino acid profile. The optimal level of inclusion of PKC could reduce the cost of egg production and improved the efficiency of production by substituting costly conventional feed ingredients with PKC ration.

Adrizal et al. (2011) indicated that native laying hens diets containing $15 \%$ or $30 \%$ of PKC with or without enzyme supplementation had similar trend in enhancement on egg production and egg internal and external quality traits (albumen height, HU and egg shell surface and thickness) compared to a corn-soyabean diet, but the yolk colour score (5-7) was significantly lower (paler) in the PKC-fed hens. A significantly lower yolk colour has also been reported for laying hens fed diets containing 25\% of PKC (Panigrahi, 1998; Chong et al., 2008). Oil extraction of $\mathrm{PKC}$ at processing plant could lead to the removal of $80 \%$ of the oil, which consequently might eliminate most of the fat-soluble vitamins from PKC, including carotenes as well. This could be the main reason of declining effects of layer feeding dietary PKC on egg yolk colour. This is in line with study by Adrizal (2010) which observed beneficial effects of PKC in combination with cassava meal supplementation as a $\beta$-carotene source in laying hen's diet has improved the egg yolk colour compared to the PKC diet alone. However, Zanu et al. (2012) revealed that egg yolk colour was significantly improved with a corresponding increase in the levels of PKC in layer ration. However, Longe (1984) discovered that layer hens fed 20\% of PKC-based ration had lower egg production than hens fed a cornsoyabean-based diet, although the daily energy consumption values of the two groups of hens were comparable. In addition, Zanu et al. (2012) indicated that diets containing 15\% PKC adversely affected egg production but did not affect egg weight (which ranged from $62.48 \mathrm{~g}$ to $68.53 \mathrm{~g}$ ), egg shell thickness or HU score compared to the control diet. Whereas, Adrizal et al. (2011) indicated that feeding laying hens with diet containing 15\% PKC had better effects on egg production and egg quality. Differences in PKC effects on egg production and quality at similar inclusion level indicated that, PKC might exert beneficial or detrimental effect depending on their substance chemical properties such oil content, CF level and shell content of the PKC obtained from different milling industry.

Nevertheless, more studies revealed that egg production and egg quality decline with the inclusion of $>50 \%$ of PKC in laying hens' diet (Perez et al., 2000; Afolabi et al., 2012; Sharmila et al., 2014). Laying hen fed with high volume of PKC might show poor efficiency of food conversion into eggs and lower egg production due to the high $\mathrm{CF}$ content of PKC diets, which can lead to impaired nutrient digestibility and absorption, particularly in the case of amino acids, and also to nutrient imbalance rather than their energy requirements. Low availability of amino acids at the increasing levels of PKC may not meet the requirements for optimum egg production, hence the reduced rate of lay.

\section{EFFECTS OF POME ON LAYING HENS' EGG PRODUCTION AND EGG QUALITY TRAITS}

POME, a by-product of CPO production that contains mainly fruit cell debris and oil from the palm mesocarp, is obtained by decanting the liquid waste. Commonly, dehydrated POME contains 12.5\% CP and $20.1 \% \mathrm{CF}$ and can be used as an alternative feed ingredient for poultry diet (Yeong, 1980). However, based on animal feeding trials, it was recommended that dehydrated POME should be used in poultry feed in limited amounts, i.e., 5\% and $10 \%-15 \%$ in the diets of broilers and laying hens, respectively, owing to its high CF $(11.5 \%-32.7 \%)$ and ash content $(9 \%-25 \%)$ and its low digestible amino acid content (Sinurat, 2003). Appropriate amount of dehydrated POME in layer ration could result in optimal egg production of laying hens.

There are several commercial feeds derived from POME with enhanced nutritive value. The POME have been converted to potential feedstuff by using a fermentation process (anaerobic, acidophilic and thermophilic), followed by concentration (decantation down to 15\%-20\% DM) (Pérez et al., 1999; Chavalparit et al., 2006). The sludge-fermented product (SFP) has been known as treated POME had increased protein, metabolisable energy and in vitro soluble phosphorus, and reduced the CF content that can be used as feed ingredients for poultry (Mirnawati et al., 2019). The treated POME can be incorporated into broiler or layer diets as a protein source to replace $30 \%$ of soyabean meal. However, the recommended optimal level of the treated POME or SFP inclusion rate in laying hens diet was 10\% (Yeong, 1980).

A study by Yeong (1987) had found average percent HDP, total egg mass and feed conversion (FI:gain in egg mass) were 76.4\%, $8.9 \mathrm{~kg}$ and 2.77:1, respectively, was obtained in hens fed the diet containing 10\% treated POME compared with $77.9 \%, 9.2 \mathrm{~kg}$ and 2.52:1, respectively, for the cornsoyabean meal reference diet. Inferior results were apparent in those layers fed diets with more than $10 \%$ treated POME. This result implies that diets containing higher levels of treated POME $(>10 \%)$ may be lacking in some of the nutrients required 
to support optimal egg production, particularly because neither diet contains animal protein. However, egg quality (egg specific gravity, percent yolk, albumen and shell weight, yolk index and HU) was not affected by the inclusion of different levels of treated POME in laying hens' diets. Yeong (1987) also reported that dehydrated POME with $13.0 \% \mathrm{CP}$ could be used at levels of up to $20 \%$ in laying hens' diets without detrimental effects on egg production. In general, dried portion of POME, which was in fermented form or dehydrated mechanically in the raw form is likely incorporated in layers or broilers rations.

The nutrient levels and quality of dry POME could also be increased by fermentation using lignocellulolytic fungi (Nuraini and Trisna, 2017). Fermentation with lignocellulolytic fungi, produce a variety of lignocellulolytic enzymes which are responsible for the biodegradation of lignocellulosic agro-wastes in nature (Govumoni et al., 2015). Lignocellulolytic enzymes such as cellulase, ligninase, xylanase and mannanase can reduce the CF levels and, improve the apparent metabolisable energy (AMEn) and availability of nutrients in dehydrated POME. Since PKC and POME are both obtained from oil palm fruit, a similar pattern of
NSP consisting of mannan-oligosaccharide as a prebiotic source may occur in both materials. Sinurat et al. (2008) reported that substitution of $25 \%$ corn with dry POME or with the multienzyme treated POME slightly improved egg production, FI and FCR in laying hens. However, substitution of 50\% corn with the multienzyme treated POME slightly reduced the FI and impaired the egg production and the FCR.

There has recently been much interest in using POME, compared to PKC by researchers as an alternative feedstuff for laying hens with regard to its nutritional values, abundant availability and low cost, also the advantage of its high-fat content and high energy ingredient source to be used in layer ration formulations. Moreover, practically there are fewer studies reported on using various biotechnological treatment methods of POME, which might be contributing to increased optimum inclusion level of POME in laying hens' feeding and improved laying hen's performance and egg production. Increasing the consumption of POME by livestock, particularly in poultry has been proposed as a means of an efficient approach to minimise environmental problems due to its highly polluting properties.

TABLE 2. ADVANTAGES AND DISADVANTAGES OF CRUDE PALM OIL AND CO-PRODUCTS OF PALM OIL MILLING ON LAYING HENS' FEEDING AND EGG QUALITY TRAITS

\begin{tabular}{|c|c|c|}
\hline $\begin{array}{l}\text { Oil palm products } \\
\text { and co-products }\end{array}$ & Advantages & Disadvantages \\
\hline $\begin{array}{l}\text { Crude palm oil } \\
(\mathrm{CPO})\end{array}$ & $\begin{array}{l}\text { Improve the performance of pullets when fed up to } 5 \% \text { of diet. } \\
\text { Economically feasible to substitute part of the maize in feed. } \\
\text { Improves palatability of diet. } \\
\text { Stimulates feed and metabolisable energy (ME) consumption. } \\
\text { Increase vitamin E (tocopherol and tocotrienol) and carotenoids } \\
\text { contents in eggs. } \\
\text { Increase egg weight and size. } \\
\text { Reduce egg cholesterol. } \\
\text { Inhibition of lipid oxidation in egg. }\end{array}$ & $\begin{array}{l}\text { Lower digestibility of CPO in young } \\
\text { birds. } \\
\text { Higher saturation and unesterified fatty } \\
\text { acids content decrease digestibility in } \\
\text { bird. } \\
\text { Saponification with feed minerals and } \\
\text { decreased absorption of calcium (Ca) } \\
\text { and phosphorus }(\mathrm{P}) \text {. }\end{array}$ \\
\hline
\end{tabular}

Palm kernel cake Produce in large amounts and low cost. (PKC)

Satisfactory dietary substitute for wheat middlings in layer diet. Optimum inclusion up to $20 \%-30 \%$ in diet with no adverse effects on growth performance or egg quality traits.

Incorporation of $30 \%$ premium grade PKC as substitute for $25 \%$ of corn and $5 \%$ of soyabean in diet improve growth performance.

Palm oil mill effluent (POME)/ palm oil sludge (POS)
Economical replacement for maize (regular diet constituent) and soyabean.

Dehydrated POME used to replace part of the protein and energy sources in layer diets.

Rich content of organic matter.

Optimum inclusion level is 5\%-10\% depending on the process (fresh, dried, and fermented).

Dry POS is low in fibre (16.8\%) content and high in protein content $(13.0 \%)$ improve egg production.

Fat-rich substrate help improve egg quality.
Lower crude protein (CP) level.

High in fibre content.

High in non-starch polysaccharides.

Lower protein digestibility of PKC diet.

More than $40 \%$ of PKC show deleterious effects on egg production and quality.

Deficient in lysine, methionine and threonine contents.

Reduced feed intake.

Low in protein content and digestible amino acids.

High fibre content.

High moisture content makes it difficult to incorporate in layer diet.

More than $10 \%$ of POME depress bird feed intake. 
The advantages and disadvantages of $\mathrm{CPO}$ and co-products of palm oil milling (PKC and POME) as feed ingredient on growth performance of laying hens, egg production and egg quality traits are summarised in Table 2.

\section{CONCLUSION}

Substitution of conventional feed ingredients in the rations fed to laying hens with primary products or co-products from palm oil milling was found to be economically beneficial in improving layer performance and egg quality traits. CPO could effectively be utilised as energy sources in layer rations for the best laying performance and egg quality when added at assigned ME values. Inclusion of PKC and POME at levels of up to 30\% and 10\%, respectively, had no detrimental impact on laying hen's performance or on egg production. These co-products have the potential for use as ingredients in commercial layer rations in oil palm producing countries due to their contribution to developing a cost-effective feeding system and possibly to reducing the adverse environmental impact of liquid waste (POME) from milling. Use of the primary and co-products from the palm oil milling industry should be intensified to further expand their use in improving the egg production and quality as well as improving the growth performance in laying hens.

\section{ACKNOWLEDGEMENT}

The authors are particularly grateful to the DirectorGeneral of MPOB for permission to publish this article.

\section{REFERENCES}

Abdeltawab, A M and Khattab, M SA (2018). Utilization of palm kernel cake as a ruminant feed for animal: A review. Asian J. Biological Sciences, 11(4): 157-164.

Abdulla, N R; Loh, T C; Akit, H; Sazili, A Q; Foo, H L; Kareem, K Y; Mohamad, R and Abdul Rahim, $R$ (2017). Effects of dietary oil sources, calcium and phosphorus levels on growth performance, carcass characteristics and bone quality of broiler chickens. J. Applied Animal Research, 45(1): 423-429.

A'dilah, M M and Alimon, A R (2011). Improving the nutritive value of palm kernel cake (PKC) through chemical pre-treatment and fungal fermentation. Proc. of the 32 ${ }^{\text {nd }}$ Annual Conference Malaysian Society of Animal Production (MSAP). p. 39.
Adrizal, A (2010). Cassava meaf meal inclusion in palm kernel meal diet could improve egg yolk color in post-molted native laying hens. International Seminar on Tropical Animal Production (ISTAP). p. 325-331.

Adrizal, A; Yusrizal, Y; Fakhri, S; Haris, W; Ali, E and Angel, C R (2011). Feeding native laying hens diets containing palm kernel meal with or without enzyme supplementations: 1 . Feed conversion ratio and egg production. J. Applied Poultry Research, 20(1): 40-49.

Afolabi, K D; Akinsoyinu, A O; Omojola, A B and Abu, O A (2012). The performance and egg quality traits of Nigerian local hens fed varying dietary levels of palm kernel cake with added palm oil. J. Applied Poultry Research, 21(3): 588-594.

Akpodiete, O J (2008). Performance response and egg qualities of laying birds fed enzyme supplemented palm kernel cake, PKC based diets. Animal Research International, 5(1): 819-822.

Akter, Y; Kasim, A; Omar, H and Sazili, A Q (2014). Effect of dietary crude palm oil on quality and oxidative stability of chicken eggs. J. Food, Agriculture and Environment, 12(3/4): 179-181.

Alimon, A R and Wan Zahari, W M (2012). Recent advances in the utilization of oil palm by-products as animal feed. Proc. of the International Conference on Livestock Production and Veterinary Technology (ICARD). 1-4 October 2012, Bogor, Indonesia. p. 211-219.

Alshelmani, M I; Loh, T C; Foo, H L; Lau, W H and Sazili, A Q (2014). Biodegradation of palm kernel cake by cellulolytic and hemicellulolytic bacterial cultures through solid state fermentation. The Scientific World Journal: Article ID 729852. http:// dx.doi.org/10.1155/2014/729852

Alshelmani, M I; Loh, T C; Foo, H L; Lau, W H and Sazili, A Q (2013). Characterization of cellulolytic bacterial cultures grown in different substrates. The Scientific World Journal: Article ID 689235. http:/ / dx.doi.org/10.1155/2013/689235

Alshelmani, M I; Loh, T C; Foo, H L; Sazili, A Q and Lau, W H (2017). Effect of solid state fermentation on nutrient content and ileal amino acids digestibility of palm kernel cake in broiler chickens. Indian J. Anim. Sci., 87: 1135-1140.

Alshelmani, M I; Loh, T C; Foo, H L; Sazili, A Q and Lau, W H (2016). Effect of feeding different levels of palm kernel cake fermented by Paenibacillus polymyxa ATCC 842 on nutrient digestibility, intestinal morphology, and gut microflora in broiler chickens. Animal Feed Science and Technology, 216: 216-224. 
Areerob, P; Dahlan, W and Angkanaporn, K (2018). Dietary crude palm oil supplementation improves egg quality and modulates tissue and yolk vitamin E concentrations of laying hen. Animal Production Science, 59(8): 1491-1500.

Atabo, S M; Umar, A A; Shehu, S A; Abdullahi, J and Yabo, Y A (2018). The efficacy of peanut oil and palm oil in preserving chicken eggs in a tropical environment. Sokoto J. Veterinary Sciences, 16(2): 106-111.

Chavalparit, O; Rulkens, W H; Mol, A P J and Khaodhair, S (2006). Options for environmental sustainability of the crude palm oil industry in Thailand through enhancement of industrial ecosystems. Environment, Development and Sustainability, 8(2): 271-287.

Chen, W L; Liang, J B; Jahromi, M F; Abdullah, N; Ho, Y W and Tufarelli, V (2015). Enzyme treatment enhances release of prebiotic oligosaccharides from palm kernel expeller. BioResources, 10(1): 196-209.

Chong, C H; Zulkifli, I and Blair, R (2008). Effects of dietary inclusion of palm kernel cake and palm oil, and enzyme supplementation on performance of laying hens. Asian-Australasian J. Animal Sciences, 21(7): 1053-1058.

Dairo, F A S and Fasuyi, A O (2008). Evaluation of fermented palm kernel meal and fermented copra meal proteins as substitute for soybean meal protein in laying hens diets. J. Central European Agriculture, 9(1): 35-44.

Daud, M J and Jarvis, M C (1992). Mannan of oil palm kernel. Phytochemistry, 31(2): 463-464.

Düsterhöft, E M; Posthumus, M A and Voragen, A G J (1992). Non-starch polysaccharides from sunflower (Helianthus annuus) meal and palmkernel (Elaeis guineensis) meal-investigation of the structure of major polysaccharides. J. Science of Food and Agriculture, 59(2): 151-160.

ENC (2014). Egg Nutrition Council. http://enc. org.au/faq/, assessed on 24 April 2019.

FAO (2018). The state of food insecurity in the world. www.fao.org/publications, assessed on 12 April 2019. 239 pp.

FAO (2002). Small scale palm oil processing in Africa. FAO Agricultural Services Bulletin, 148: 1-56.

Foong, S Z; Andiappan, V; Tan, R R; Foo, D C and $\mathrm{Ng}, \mathrm{D} \mathrm{K}$ (2019). Hybrid approach for optimisation and analysis of palm oil mill. Processes, 7(2): 100.
Goh, S H; Choo, Y M and Ong, S H (1985). Minor constituents of palm oil. J. Amer. Oil Chem. Soc., 62(2): 237-240.

Govumoni, S P; Gentela, J; Koti, S; Haragopal, V; Venkateshwar, S and Rao, L V (2015). Extracellular lignocellulolytic enzymes by Phanerochaete chrysosporium (MTCC 787) under solid-state fermentation of agro wastes. International J. Current Microbiology and Applied Sciences, 4(10): 700-710.

Halim, R M; Ramli, R; Che Mat, C R; Hadi, N A; Bakar, N A and Aziz, A A (2017). Highly digestible palm kernel cake (PKC) for animal feed. $M P O B$ Information Series No. 758: 4 pp.

Hodzic, A; Hamamdzic, M; Gagic, A; Mihaljevic, M; Vegara, M; Krnic, J and Pasic, E J (2008). The influence of dietary palm olein, fish oil and lard on the egg yolk and plasma lipid composition, and performances of laying hens. Polish J. Veterinary Sciences, 11(1): 1-7.

Iyayi, E A and Aderolu, Z A (2004). Enhancement of the feeding value of some agro-industrial byproducts for laying hens after their solid state fermentation with Trichoderma viride. African J. Biotechnology, 3(3): 182-185.

Kang, K R; Cherian, G and Sim, J S (1998). Tocopherols, retinol and carotenes in chicken egg and tissues as influenced by dietary palm oil. J. Food Science, 63(4): 592-596.

Kang, K R; Cherian, G and Sim, J S (2001). Dietary palm oil alters the lipid stability of polyunsaturated fatty acid-modified poultry products. Poultry Science, 80(2): 228-234.

Koelkebeck, K W; DePersio, S; Lima, K; Harrison, P C; Utterback, C; Utterback, P and Campbell, J M (2014). Evaluation of feeding spray-dried bovine plasma protein on production performance of laying hens exposed to high ambient temperatures. J. Applied Poultry Research, 23(3): 393-402.

Longe, O G (1984). Effects of increasing the fibre content of a layer diet. British Poultry Science, 25(2): 187-193.

Longe, O G and Adekoya, O E (1988). Response of laying hens to different inclusion levels of palm kernel meal and vegetable oil. Nigerian J. Animal Production, 15: 111-117.

Marini, A M; Daud, M J; Noraini, S; Jame Ah, H and Azahan, E E (2005). Performance of locally isolated microorganism in degrading palm kernel cake $(\mathrm{PKC})$ fibre and improving the nutritional value 
of fermented PKC. J. Tropical Agriculture and Food Science, 33(2): 311.

Mirnawati, M; Ciptaan, G and Djulardi, A(2019). The combined effects of fungi Phanerochaete chrysosporium and Neurospora crassa and fermentation time to improve the quality and nutrient content of palm oil sludge. Pakistan J. Nutrition, 18(5): 437-442.

Mohamed, W Z; Alimon, A R and Wong, H K (2012). Utilization of oil palm co-products as feeds for livestock in Malaysia. Biofuel Co-products as Livestock Feed: Opportunities and Challenges. FAO Publications, Rome, Italy. p. 243-262.

Muangkeow, N and Chinajariyawong, C (2013). Diets containing fermented palm kernel meal with Aspergillus wentii TISTR 3075 on growth performance and nutrient digestibility of broiler chickens. Walailak J. Science and Technology, 10(2): 131-147.

Muangkeow, N and Chinajariyawong, C (2009). Determination of true amino acid digestibility and metabolizable energy in fermented palm kernel meal with Aspergillus wentii TISTR 3075 for chickens. Walailak J. Science and Technology, 6(2): 231-241.

Nuraini, A D and Trisna, A (2017). Palm oil sludge fermented by using lignocellulolytic fungi as poultry diet. International J. Poultry Science, 16: 6-10.

Odunsei, A A; Akande, T O; Yusuph, AS and Salami, R I (2002). Comparative utilisation of high inclusion rates of four agro-industrial by-products in the diets of egg type chickens. Archivos De Zootecnia, 51(196): 465-468.

Onwudike, O C (1988). Palm kernel meal as a feed for poultry. 4. Use of palm kernel meal by laying birds. Animal Feed Science and Technology, 20(4): 279-286.

Onwudike, O C (1992). Effect of blood meal on the use of palm kernel meal by laying birds. Proc. of the XIX World's Poult. Congr. p. 55-58.

Palmquist, D L (2004). Palm fats for livestock feeding. Palm Oil Developments No. 40: 10-16.

Panda, A K and Cherian, G (2014). Role of vitamin $\mathrm{E}$ in counteracting oxidative stress in poultry. The J. Poultry Science, 51: 109-117.

Panigrahi, S (1998). Use of rations with up to forty percent palm kernel meal for egg production. British Poultry Science, 39(S1): 37-38.

Perez, J F; Gernat, A G and Murillo, J G (2000). The effect of different levels of palm kernel meal in layer diets. Poultry Science, 79(1): 77-79.
Pérez, M; Romero, L I and Sales, D (1999). Anaerobic thermophilic fluidized bed treatment of industrial wastewater: Effect of F: M relationship. Chemosphere, 38(14): 3443-3461.

Ping, B T Y and Gwendoline, E C L (2006). Identification of lutein in crude palm oil and evaluation of carotenoids at various ripening stages of the oil palm fruit. J. Oil Palm Res. Vol. 18: 189-197.

Punita, A and Chaturvedi, A (2000). Effect of feeding crude red palm oil (Elaeis guineensis) and grain amaranth (Amaranthus paniculatus) to hens on total lipids, cholesterol, PUFA levels and acceptability of eggs. Plant Foods for Human Nutrition, 55(2): 147-157.

Qureshi, A A N; Qureshi, J J K; Wright, Z; Shen, G; Kramer, A; Gapor, Y H; Chong, Y H; Dewitt, G; Ong, A S H; Peterson, D M and Bradlow, A B (1991). Lowering of serum cholesterol in hypercholesterolemic humans by tocotrienols (paten-tee). The Amer. J. Clinical Nutrition, 53: 1021S-1026S.

Radim, D; Alimon, A R and Yusnita, Y (2000). The effect of replacing corn with rice bran and palm kernel cake in layer rations. Proc. of the $22^{\text {nd }}$ Malaysian Society of Animal Production Annual Conference. 29 May - 1 June 2000, Kota Kinabalu, Sabah, Malaysia. p. $177-178$.

Rahim, F; Sabrina, S; Rusmawati, R and Syibli, M (2007). Broiler small intestine villi response to feed containing palm kernel cake which fermented with Rhizopus sp. J. Indonesian Tropical Animal Agriculture, 32(4): 251-256.

Saenphoom, P; Liang, J B; Ho, Y W; Loh, T C and Rosfarizan, M (2013). Effects of enzyme treated palm kernel expeller on metabolizable energy, growth performance, villus height and digesta viscosity in broiler chickens. Asian-Australasian J. Animal Sciences, 26(4): 537.

Sandeski, L M; Ponsano, E H and Neto, M G (2014). Optimizing xanthophyll concentrations in diets to obtain well-pigmented yolks. J. Applied Poultry Research, 23(3): 409-417.

Shakila, S and Reddy, P S (2012). The utilization of palm kernel meal in laying hen diet. Indian J. Poultry Science, 47(1): 79-83.

Sharmila, A; Azhar, K; Hezmee, M N and Samsudin, A A (2014). Effect of xylanase and cellulase supplementation on growth performance, volatile fatty acids and caecal bacteria of broiler chickens fed with palm kernel meal-based diet. J. Animal and Poultry Sciences, 3(1): 19-28. 
Sinurat, A P (2003). Utilization of palm oil sludge for poultry feed. WARTAZOA Indonesian Bulletin of Animal and Veterinary Sciences, 13(2): 39-47.

Sinurat, A P; Purwadaria, T; Bintang, I A K; Pasaribu, T; Manurung, B P and Manurung, N (2008). Substitution of corn with enzymes treated palm oil sludge in laying hens diet. Proc. of the XXIII World's Poult. Sci. Congress. 6 pp.

Soltan, M A (2009). Growth performance, immune response and carcass traits of broiler chicks fed on graded levels of palm kernel cake without or with enzyme supplementation. Livestock Research for Rural Development, 21(3): 37.

Sundu, B and Dingle, J G (2003). Use of enzymes to improve the nutritional value of palm kernel meal and copra meal. Queensland Poult. Sci. Symp., 11(14): 1-15.

Sundu, B; Kumar, A and Dingle, J (2006). Palm kernel meal in broiler diets: Effect on chicken performance and health. World's Poultry Science J., 62(2): 316-325.

Swain, B K; Naik, P K and Singh, N P (2014). Unconventional feed resources for efficient poultry production. Technical Bulletin No. 47: 65 pp. ICARICAR Research Complex for Goa, India.

Tafsin, M; Hanafi, N D and Yusraini, E (2017). Extraction process of palm kernel cake as a source of mannan for feed additive on poultry diet. IOP Conference Series: Earth and Environmental Science, Vol. 65. No. 1: 012020.

Tomkins, T and Drackley, J K (2010). Applications of palm oil in animal nutrition. J. Oil Palm Res. Vol. 22: 835-845.

Tranbarger, T J; Dussert, S; Joët, T; Argout, X; Summo, M; Champion, A and Morcillo, F (2011). Regulatory mechanisms underlying oil palm fruit mesocarp maturation, ripening, and functional specialization in lipid and carotenoid metabolism. Plant Physiology, 156(2): 564-584.

Walker, L A; Wang, T; Xin, H and Dolde, D (2012). Supplementation of laying-hen feed with palm tocos and algae astaxanthin for egg yolk nutrient enrichment. J. Agricultural and Food Chemistry, 60(8): 1989-1999.

Wu, L; Guo, X; Wang, W; Medeiros, D M; Clarke, S L; Lucas E A and Lin, D (2016). Molecular aspects of $\beta, \beta$-carotene-9', 10'-oxygenase 2 in carotenoid metabolism and diseases. Experimental Biology and Medicine, 241(17): 1879-1887.

Yao, L; Wang, T; Persia, M; Horst, R L and Higgins, M (2013). Effects of vitamin D3-enriched diet on egg yolk vitamin D3 content and yolk quality. J. Food Science, 78(2): C178-C183.

Yeong, S W (1980). The nutritive value of palm oil by-products for poultry. Proc. of the $1^{\text {st }}$ AsianAustralasian Animal Science Congress. Abstr. No. 45. p. 17.

Yeong, S W (1987). The use of palm oil by-product (POME) as feed for laying chickens in Malaysia. Proc. of the $4^{\text {th }}$ AAAP Animal Science Congress. p. 211.

Yeong, S W; Mukherjee, T K and Hutagalung, R I (1981). The nutritive value of palm kernel cake as a feedstuff for poultry. Proc. of Nat. Workshop on Oil Palm By-product Utilization. p. 100-107.

Yusrizal, Y; Angel, R; Adrizal, A; Wanto, B E; Fakhri, $S$ and Yatno, Y (2013). Feeding native laying hens diets containing palm kernel meal with or without enzyme supplementations. 2. Excreta nitrogen, ammonia, and microbial counts. J. Applied Poultry Research, 22(2): 269-278.

Zanu, H K; Abangiba, J; Arthur-Badoo, W; Akparibo, A D and Sam, R (2012). Laying chickens response to various levels of palm kernel cake in diets. International J. Livestock Production, 3(1): 12-16. 